\title{
Business Innovation Intensity within Creative Services Businesses in Indonesia
}

\author{
Mien Mien", Chrisanty V. Layman2 ${ }^{\#}$ \\ * Pelita Harapan University \\ Management Study Program \\ MH Thamrin Boulevard 1100, Banten 15811, Indonesia \\ E-mail: mienmienteo@gmail.com \\ \# Pelita Harapan University \\ Management Study Program \\ MH Thamrin Boulevard 1100, Banten 15811, Indonesia \\ E-mail: chrisanty.layman@uph.edu
}

\begin{abstract}
Abstrak
Di era New Normal Indonesia, kreativitas merupakan aspek penting bagi bisnis. Penelitian sebelumnya mengemukakan adanya hubungan antara dukungan tim, persepsi individu, intensitas inovasi tim dan perusahaan pada mahasiswa yang sudah memasuki dunia kerja. Penelitian ini membahas pengaruh persepsi individu, persepsi dukungan tim terhadap intensitas inovasi bisnis jasa yang dimediasi oleh intensitas inovasi tim. Pengumpulan data dilakukan dengan menyebarkan kuesioner secara daring kepada 204 karyawan yang bekerja pada usaha jasa industri kreatif di Indonesia. Hasil penelitian menemukan bahwa persepsi keterampilan kreativitas individu berpengaruh positif terhadap persepsi dukungan tim terhadap inovasi, dan persepsi dukungan tim terhadap inovasi berpengaruh positif terhadap intensitas inovasi perusahaan. Selanjutnya, hubungan antara persepsi dukungan tim untuk inovasi dan intensitas inovasi perusahaan kewirausahaan sebagian dimediasi oleh intensitas inovasi tim.
\end{abstract}

Kata kunci: intensitas inovasi, inovasi tim, persepsi dukungan tim, wirausaha perusahaan, persepsi keterampilan kreativitas individu, industri kreatif, dan usaha jasa

\begin{abstract}
In Indonesia's New Normal era, creativity is an important aspect for businesses. Previous research suggests the relationship between team support, individual perceptions, the intensity of team and company innovation on students who have entered the world of work. This study explores the effect of individual perceptions, perceptions of team support on the intensity of service business innovation which is mediated by the intensity of team innovation. Data collection was carried out by distributing online questionnaires to 204 employees who work in creative industry service businesses in Indonesia. The study found that perception of individual creativity skills had a positive effect on perceptions of team support for innovation, and perceptions of team support for innovation had a positive effect on the intensity of company innovation. Furthermore, the relationship between perceptions of team support for innovation and entrepreneurial firm innovation intensity is partially mediated by team innovation intensity.
\end{abstract}

Keywords: innovation intensity, team innovation, perceptions of team support, entrepreneurial firm, perceptions of individual creativity skills, creative industry, and service business

\section{Introduction}

In today's knowledge-driven economy, maximizing innovation has become a top priority in every company. With the high intensity of innovation, companies can have a competitive advantage through differentiation and continuous improvement of their products or services. Currently, the success of a business depends on entrepreneurs who can find the most creative solutions to pressing problems, therefore entrepreneurship requires ideas that have not been thought of by others before, an idea that is creative and innovative [1]. To cope with a rapidly changing and 
increasingly competitive environment, adaptability, flexibility, risk-taking, productivity, aggressiveness, and innovation are the most needed, in other words, entrepreneurship [2]. In addition, innovation is also a prerequisite for economic development in a company, especially in developing countries, where innovation is an important factor for the transition to development [3]. The more companies look for ways to increase creativity and efficiency in their employees, the more competitive advantage can be achieved [4]. In the workplace, creativity and innovation are processes, outcomes, and products of efforts to develop and introduce new and better ways of doing work start from forming an idea until those ideas and innovations become better procedures, practices, or products are being implemented [5].

Based on data from the Global Innovation Index (GII) in 2020, Indonesia is ranked 85th among 131 economies worldwide, where for 3 consecutive years, the Indonesian state has not increased and remains as $85^{\text {th }}[6]$. Data on creative industry innovation shows that Indonesia has not been included in the group of advanced industrial countries in the world because there are still many problems in developing the national industry, one of which is the low number of business actors in the creative industry sector [7]. Based on data from Bekraf and the Central Statistics Agency, Indonesia's creative industry still faces serious challenges in finance, around $92.4 \%$ of industry players did not receive outside funding in 2017 [8]. Therefore, the creative industry in Indonesia is constantly required to increase the level of innovation to increase the added value of products and make a significant contribution to the national economy. Based on data from The World Bank (2019), service companies in Indonesia also have a small contribution (44.2\%) to the value of world Gross Domestic Product (GDP) [9]. Companies that compete in the creative industry face a market characterized by diverse and changing customer tastes, so the ability to develop innovations is not only to be achieved but also to maintain a competitive advantage in the sector [10]. For service companies in the creative industry to survive, firm innovation intensity is highly important.

In the creative industry, entrepreneurship plays a role in encouraging innovation, intellectual property protection, and dynamic market competition so that it can benefit economic revival and development [11]. In addition, personal ideas, talents, experience, and work are important for this industry [12]. The success of entrepreneurship in the creative sector is also greatly influenced by the company's creative performance which refers to innovative results in the form of products, services, and processes and procedures [13]. With market dominance that has begun to move from products to services [14], service companies in this industry are in a very competitive and changing environment, therefore a creative and innovative workforce is needed to provide high-quality services [15]. The main challenge in the service business is the problem between personalization and service standardization, which is fundamental to service innovation provided [16].

Although several studies concur that creativity is one of the main contributors to organizational innovation and competitive advantage in a dynamic environment [4], [17], [18], however research gap still exist on the contribution aspects of the individual's creativity. Creative individual workers with the ability to see solutions that others cannot see are needed in a company or business [19]. In addition, creative workers can also facilitate the process of creating value in products or services in the creative sector, more things like knowledge, intelligence, and creativity embedded in creative employees can be considered as the company's intellectual capital [20] When creative employees have access to the right conditions, opportunities, and environment, they will generate and encourage new product and service innovations [21], [22]. When individuals show creativity and innovation, they can complete their tasks better, thereby increasing organizational performance and competitive advantage in an uncertain environment [23], the higher the individual's ability to generate ideas, the more it will contribute to the group and organizational innovation [24]. In the context of the creative industry, teams are very much used in the innovation process, with their capacity to produce new solutions quicker, teams can adapt to changing customer tastes and market conditions [10]. For this reason, each team member who can contribute through sequential interactions and is willing to accept change can work as a genuine team.

While most service innovation studies has been carried out in developed market where the service sector has been dominant for decades, this study focuses on emerging markets such as Indonesia that are still going through various stages of economic growth. In addition, a working framework regarding the unique challenges faced by creative businesses also need to be established [25]. Therefore, this study attempts to analyze the important creative actors themselves within developing small-business and micro-businesses looking at the perceptions of individual creativity skills and perceptions of team support for innovation against entrepreneurial innovation intensity mediated by team innovation intensity in the creative service business in Indonesia.

\section{Literature Review}

2.1 Perceptions of Individual Creativity Skills 
Creativity is a behavior of personal characteristics, cognitive abilities, and social environment with the ability to generate new and appropriate ideas. Creativity is defined in the Oxford dictionary as "the use of imagination or skills to create something new" and creating something brilliant is said as "the fuel" for innovation [19]. Individual creativity arises when individuals collect and process job information in generating new ideas [26]. Employee involvement in the creative process starts from identifying problems, building hypotheses, exchanging ideas with others, and challenging the status quo that can produce new and useful solutions or ideas. In this case, individuals need to focus not only on the novelty of ideas but also on the usefulness of the resulting ideas so that individuals tend to distinguish which new ideas are useful for solving problems [26]. Terms related to perception include attitudes, conceptions, implicit theories, and views, in this case, the perception of individual creative skills as the belief in individual creativity and individual beliefs in thinking about new and useful ideas [27].

\subsection{Perceptions of Team Support for Innovation}

Team support is the support that comes from a group of individuals who depend on each other in carrying out their duties and are responsible for the results they get, wherewith team support, will encourage cooperation, synergy, and increase the efficiency of each member in the team. take advantage of each other's strengths [28]. Perceptions of team support for innovation refer to the degree to which team members co-allocate resources in development, encourage the expression of new ideas, spend time developing creative ideas and take action to implement those ideas [29]. Support for innovation is "hope, approval and practical support of efforts to introduce new, better ways of doing things in the work environment" [30]. With support in the form of freedom to make decisions, freedom to direct attention, and the urge to take risks, the ability of individuals who pursue innovation can be generated [31].

Innovation is more likely to occur in groups when members have decided to be innovative with consequent support for innovation, therefore, innovation support in teams plays an important role in promoting innovation in teamwork with the feeling that their creative ideas are encouraged and expected [29]. Individual and team creativity provides important support in innovation, without creative ideas, no innovation can be applied [32], [33]. The success of a new product or innovation in a team starts from the creativity of each team member [34], [35]. When team members learn from different perspectives in a supportive and reflective team, team members are more likely to engage in elaborating information to produce creative results [36]. The higher the perceptions of individual creative skills, the higher the perceptions of team support for innovation in a company, therefore this study hypothesizes:
Hypothesis 1: There will be a positive and significant relationship between perceptions of individual creativity and perceptions of team support for innovation.

\subsection{Team Innovation Intensity}

Team innovation intensity is conceptualized in four dimensions, namely the ratings of the magnitude, radicalness, novelty, and the impact of innovation performance produced by the team [37]. Team innovation refers to the application of new ideas in the creativity and innovation implementation stages, where team members need to take each other's perspectives together for a more comprehensive evaluation so that the team can identify useful alternative ideas and discard ideas that seem useless. Intensity means something that is very concentrated or something that has a high level of strength, so that the intensity of innovation means creating new knowledge by increasing the level of "input" for innovation [38]. Team innovation is the team's ability to generate new and creative ideas and the team's ability to implement these ideas [39]. Team innovation involves developing creative solutions, products, or services that are practical and sensible so that if a problem occurs within the team, this does not interfere with team performance in the given innovation tasks [40].

\subsection{Entrepreneurial Firm Innovation Intensity}

Entrepreneurial firm innovation intensity is conceptualized as the ability to transform innovative inputs into innovative outputs [41]. High intensity of innovation shows that companies invest heavily in innovation and reflect the organizational commitment to developing new products and services, they tend to appreciate the potential of new ideas and divert work efforts to implement the result of creative ideas [42], [43]. Several studies mention the intensity of company innovation in two types, in-house intensity, and outsource intensity, where in-house intensity, innovation refers to spending on internal innovation while in outsource intensity, innovation refers to spending on external innovation [44]. A greater level of entrepreneurship will result in greater growth and innovation [45]. From a process perspective, innovation requires two aspects, namely corporate technology innovation and the introduction of new products and services so that the extent to which entrepreneurial companies can develop and bring new products and services to the market based on these opportunities will be the indicators of basic success [46].

In innovating, the team is often at the core of innovation because the team is responsible for improving new or existing ideas while dealing with unpredictable problems [47], so that in its routine factors, innovation requires team members to be open to new ideas and ways of acting [48]. Innovative teams 
with high support in sharing and implementing new ideas, participatory decision making, and support for innovation can generate higher innovation power and effectiveness [49]. On the other hand, if the team constantly ignores or rejects new ideas or is in a state of a low level of support for innovation, all forms of novelty and innovation will be hindered [29]. Support for innovation plays an important role in promoting innovation in teams and generating innovation for companies [27], [29], [43], [50], [51], therefore this study hypothesizes:

Hypothesis 2: There will be a positive and significant relationship between perceptions of team support for innovation and entrepreneurial firm innovation intensity.

Companies with high innovation intensity will encourage efforts to implement creative ideas that result from strengthening creativity in teams [43]. If team members are not in a supportive environment and the team does not support collaborative interaction between members, then the full potential for producing good performance is not realized [52]. Conversely, if the team cohesiveness becomes stronger in innovating, the atmosphere of organizational innovation will be more harmonious [53]. The higher the level of innovation, the higher the revenue and profit growth for the innovator firms [19], [43], [46], [54]. In previous studies, innovation intensity is a mediating variable in the relationship between company performance [27], [55]. Therefore, therefore this study hypothesizes:

Hypothesis 3: The relationship between perceptions of team support for innovation and entrepreneurial firm innovation in- tensity is mediated by team innovation intensity.

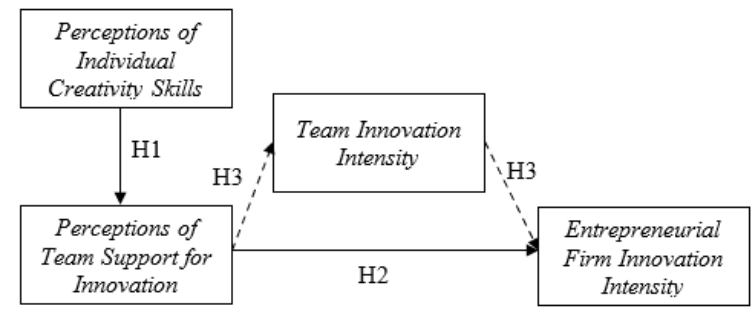

Figure 1 Proposed Model

\section{Methodology}

\subsection{Data Collection}

The sample is comprised of employees that are working in service based companies in Indonesia's creative industry. There are 204 respondents that completed the online questionnaire. Of the total sample, 158 questionnaires were usable for the purpose of this analysis. From the data collected, the length of time of employees have worked in their current firms are 41,7\% less than a year; 28,9\% 1-3 years; $15,2 \% 3-5$ years and $14,2 \%>5$ years. The number of people in a team were reported: $52 \%$ team consist of 2-5 people; $23 \% 6-10$ people and $25 \%>$ 10 people. The following firms in creative industry sector are: $(23,5 \%)$ art performing; (18,1\%) photography; (17,7\%) advertising; (13,2\%) applications and games; (9,8\%) visual communication design; $(2,5 \%)$ film, animation and video; $(2,5 \%)$ art; $(2,5 \%)$ culinary; (2\%) architecture; (2\%) interior design; $(2 \%)$ product design; (2\%) fashion; (1,5\%) publishing; (0,5\%) television and radio; $(0,5 \%)$ music.

\subsection{Measures}

Perceptions of individual creativity skills (PC) is measured by 2 indicators and perceptions of team support for innovation (PT) is measured by 5 indicators from previous research (Gundry et al, 2014). The measurement scale used is likert scale with point $1=$ strongly disagree up to point $5=$ strongly agree (point 3 = neutral point). Reliability and validity test was analysed by the value of cronbach's alpha $(\square \geqslant 0,6)$, average variance extracted $(\mathrm{AVE} \geqslant 0,5)$, composite reliability $(\mathrm{CR} \geqslant$ 0,7 ), pearson's correlation ( $\mathrm{r}$ value $>\mathrm{r}$ table; $\mathrm{r}$ table $=0,1313$ ) and the factor loadings should exceed 0,5 [56]-[60]. The team innovation intensity (TI) is measured using an indicator "My team has introduced a product or service innovation for the past 6 months". Teams involved in innovation are those that have created new products and processes for the organization during the past six months, whereas teams that have not been involved in innovation for the past six months are considered to have low innovation intensity. Entrepreneurial firm innovation intensity is measured with the same indicator as TI but asked specifically if the innovation produced by the team is introduced by the firm as a whole. The variable team innovation intensity (TI) and entrepreneurial firm innovation intensity (EI) are measured by indicators with a choice of answers: yes and no, so the scale used is a dichotomous scale. Hypothesis testing is done by the structural equation modeling (SEM) analysis technique using the SPSS 25.0 and AMOS 22.0.

\subsection{Analysis Method}

Multicollinearity statistical test was conducted with the provisions of the value of variance inflation factor (VIF), where VIF $<10.00$, the smaller the VIF value the better [61] and the provision of the value of tolerance is greater than 0.1 [62]. In analysing the actual test, all data then be selected from outlier response that was carried out by mahalanobis distance calculations through the SPSS program 
based on the chi-square distribution with a pvalue $>$ 0.001 . There were 16 data deleted as a outlier responses. The descriptive statistical test was carried out through the analysis of the mean, standard deviation, frequency, mode and variance on the variables in this study. Descriptive statistics with mean value, standard deviation, range were performed on the perceptions of individual creativity and perceptions of team support for innovation. For categorical variables, namely team innovation intensity and entrepreneurial firm innovation intensity, descriptive statistics were carried out through the frequency and mode. In the application of SEM, the assessment of the suitability of the model with the sample data is carried out by interpreting the results of parameter estimates. There are 2 indices to measure the goodness of model fit in this study, namely: Comparative Fit Index (CFI) $\geqslant$ 0.90 and the value of Root Mean Square Error of Approximation (RMSEA) with a value of $0.08-0.10$ $=$ mediocre fit and a value of $<0,01=\operatorname{good}$ fit (Thakkar, 2020).

\section{Results \& Discussion}

The results of descriptive statistics on the perceptions of individual creativity skills show a minimum value of 2 and a maximum value of 5 . The mean value of the perceptions of individual creativity skills variable is 4.05 and 4.11 . This shows that respondents have a high perception of their creative skills. In addition, the standard deviation value for the two indicators is 0.8 , smaller than the mean value obtained, so it can be concluded that the respondents' answers obtained have a low deviation rate. The results of descriptive statistics on the perceptions of team support for innovation show a minimum value of 2 and a maximum value of 5 . The mean value of the perceptions of team support for innovation variable ranges from 4.3-5. This shows that respondents have a high perception of team support for innovation. In addition, the standard deviation value for the two indicators is $0.5-0.7$, smaller than the mean value obtained, so it can be concluded that the respondents' answers have a low deviation rate.

The results of descriptive statistics on the team innovation intensity show that the respondent's tendency $($ Mode $=1)$ to answer "Yes" to the statement of the team's innovation results was introduced as a service business innovation for the last 6 months with a total of 134 data. The results of descriptive statistics on the entrepreneurial firm innovation intensity show that the tendency of respondents $($ Mode $=1)$ to answer "Yes" for the statement that the service business has innovated over the past 6 months with a total of 128 data. From the descriptive statistics obtained, it can be concluded that businesses and service companies from creative industry in Indonesia are still actively innovating.

TABle 1 Reliability TEST Results

\begin{tabular}{|c|c|c|c|}
\hline & PC & PT & Reliability \\
\hline $\begin{array}{c}\text { Cronbach's } \\
\text { Alfa }(\alpha)\end{array}$ & 0,619 & 0,815 & Reliable \\
\hline $\begin{array}{c}\text { Composite } \\
\text { Reliability }\end{array}$ & 0,816 & 0,892 & Reliable \\
\hline
\end{tabular}

TABLE 2 VALIDITy Test RESUlts

\begin{tabular}{|c|c|c|c|c|}
\hline & $\begin{array}{c}\text { Factor } \\
\text { Loading }\end{array}$ & $\begin{array}{c}\text { Pearson } \\
\text { Correlations }\end{array}$ & \multirow{2}{*}{ AVE } & Validity \\
\hline PC1 & 0,840 & 0,852 & \multirow{2}{*}{0,690} & Valid \\
\cline { 1 - 3 } PC2 & 0,821 & 0,850 & & \\
PT1 & 0,758 & 0,510 & \multirow{2}{*}{0,625} & \multirow{2}{*}{ Valid } \\
PT2 & 0,814 & 0,369 & & \\
\hline PT3 & 0,877 & 0,794 & & \\
\hline PT4 & 0,793 & 0,533 & \\
\cline { 1 - 3 } PT5 & 0,700 & 0,572 & & \\
\hline
\end{tabular}

All the study variables have showcased both good validity and reliability. The value of Cronbach's Alpha and KR actual data fulfills the $\alpha>0.6$ and $\mathrm{CR}>0.7$ (Table 1). The results of calculating Pearson correlation and AVE on all indicators fulfill the requirements of $r$ count $>\mathrm{r}$ table and value of AVE $>0.5$ (Table 2). The research model has also shown model fit, the CFI index value $=0.907($ good fit $)$ and $\mathrm{RMSEA}=0.1$ (mediocre fit) indicates that the goodness-of-fit between the data and this research model is reached (Table 3).

TABLE 3 Model Fit Results

\begin{tabular}{|c|c|c|}
\hline & Value & Model Fit \\
\hline CFI & 0,907 & Good fit \\
\hline RMSEA & 0,1 & Mediocre Fit \\
\hline
\end{tabular}

TABLE 4 DIRECT EFFECT

\begin{tabular}{|c|c|c|c|c|}
\hline Direct Effect & t-statistic & Sig. & F value & Sig. \\
\hline PC -> PT & 4,135 & 0,000 & 17,095 & 0,000 \\
\hline PT -> EI & 2,703 & 0,008 & 7,306 & 0,008 \\
\hline
\end{tabular}

Hypothesis testing is done by looking at the $\mathrm{t}$ statistic value, the calculated $F$ value and the significance value (Table 4). The t-table value in this study with alpha $5 \%$ and the number of data 158 was 1.655 , the value of the $\mathrm{F}$ table in this study was 2.66 , and the accepted significance value was sig. $<0.05$. The results of linear regression in the relationship between perceptions of individual creativity skills and perceptions of team support for innovation show the $t$ statistical value $(4,135)>$ t table $(1,655)$, the calculated F value $(17,095)>F$ table $(2,66)$ and the significance value $(\mathrm{t}$ test $=0,000$ and $\mathrm{F}$ test $=0,008)<0.05$. The $\mathrm{PC}$ coefficient value also showed a positive result $(0,550)$. From the results of the data processing, it can be concluded that the perceptions of individual creativity skills variable have a positive and significant effect on 
the perceptions of team support for innovation variable.

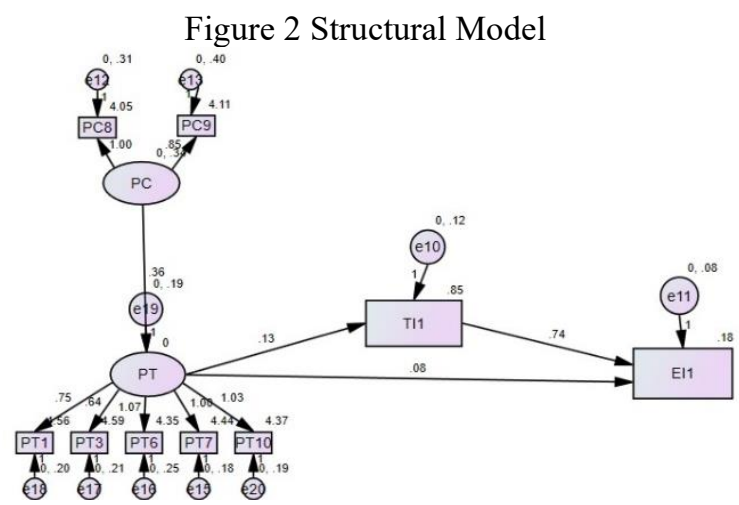

The results between perceptions of team support for innovation and entrepreneurial firm innovation intensity show that the $\mathrm{R}$ Square value $(0.085)$ ranges between 0 and 1 and is generally accepted as a measure of the amount of variation calculated through the logistic model. The coefficient value obtained is 0.085 (positive value). Based on the results of the analysis, it can be concluded that the variable perceptions of team support for innovation have a positive and significant effect on entrepreneurial firm innovation intensity.

TABLE 5 INDIRECT EFFECT

\begin{tabular}{|c|c|c|c|}
\hline Indirect Effect & $\begin{array}{c}\text { Estimate } \\
(\mathrm{a} \mathrm{x} \mathrm{b})\end{array}$ & $\mathrm{SE}_{\mathrm{ab}}$ & $\mathrm{Z}_{\text {value }}$ \\
\hline PT -> TI -> EI & 0,0992 & 0,0489 & 2,0295 \\
\hline
\end{tabular}

The results of testing the indirect relationship (mediation) between the variable perceptions of team support for innovation and entrepreneurial firm innovation intensity were tested by calculating SEab and Zvalue. The obtained Zvalue (2.0295) $>1.96$ (Table 5). This means, the team innovation intensity mediates the relationship between the variable perceptions of team support for innovation on entrepreneurial firm innovation intensity partially (there is a significant effect on the direct relationship between the perceptions of team support for innovation variable and entrepreneurial firm innovation intensity).

The level of innovation intensity of creative industry service companies is currently at a high intensity, based on the data obtained, there are $81 \%$ of companies that are producing innovations for the past 6 months. This is due to the high level of personalization and standardization that must be maintained in the service business. In providing new services, service businesses must be able to adapt to different consumer tastes. Consumer tastes also tend to change regularly. For the creative service industry, differentiation is a prioritized strategy. The creative industry service business requires special personal skills, something that is unusual and different from the others to attract the consumer's attention among existing competitors. With existing market conditions and changes that are frequently happening, innovation is an important thing to maintain business and its competitive advantage.
This is further supported with the creative industry in Indonesia must continue to be increased optimally and sustainably so that it can develop well and compete with other economic actors [63]. In addition, the creative economy is also an important issue and is the focus of the Indonesian government with the target of making Indonesia a global creative economy player in 2030 [8]. To survive in this rapid economy, service businesses must always be creative and be proactively find solutions to existing problems and take advantage of every opportunity that exists. Creativity is an important key to finding effective solutions and new innovative ideas. The results of this study prove that the perceptions of individual creative skills have a positive and significant effect on perceptions of team support for innovation. This shows that in creativity, the level of individual confidence in generating new and useful ideas requires support from their work team. The average value of the data obtained for perceptions of individual creativity skills shows that employees have a high perception of their creative skills. This means employees who work in creative service businesses in Indonesia believe that they are creative in thinking about new and useful ideas in their workplace. With this high perception, employees will be more likely to cultivate the creativity of teammates in the workplace.

Nowadays, teams play an important role in the overall performance of a company. Teams have become an important asset to the company. When there are more people involved, the business will get a greater source of good ideas. With a supportive team, individuals can explore broader ideas with other members, besides that, individuals will also be increasingly involved in generating creative ideas. Based on the data obtained, most respondents work as a team in 15 types of creative industry fields, the majority are in the performing arts $(23.5 \%)$. In terms of the number of members in a team, the majority consists of $2-5$ people $(52 \%)$ and many of the teams that carry out innovation are in the marketing field $(26 \%)$. Based on the data obtained, the intensity of service business innovation produced by the team is at a high level, there are $84.8 \%$ of teams that have introduced innovations in the last 6 months. This means, in the daily operations of a service business, most of the employees have worked as a team to produce innovation, not individually. Besides, teams with high creative beliefs are effective in generating innovation for creative service businesses.

Based on the National Long Term Development Plan (RPJPN) of 20 years 2005-2025, Indonesia plans to achieve per capita income equivalent to middle income countries in 2025 with the highest GDP contributor to the service sector, which represents around $45.4 \%$ of the total GDP [64]. With the dominance of markets moving from the product to be a service, the service company in this industry is in a very competitive and changing environment so that creative and innovative 
workers are needed to provide high-quality services [65]. So although creative ideas have not been a successful innovation, innovation remains the most important thing for innovative companies who are looking for positions on the market or for new service profiles [66].

This study proves that the perceptions of team support for innovation have a positive and significant effect on entrepreneurial firm innovation intensity. The higher the perceptions of the support team for innovation, the higher the entrepreneurial firm innovation intensity will be. This happens because of the high support conditions given, employees will be more open to innovate and provide better performance for the company. With higher perceived team support for innovation, it can also direct the company or business to generate innovations regularly compared to the perceived team support is lower. This supported with the idea that employees with creativity that implements new ideas are the first step in service innovation activities [67].

Furthermore, the results of this study also indicate that team innovation intensity mediates the relationship between perceptions of team support for innovation and entrepreneurial firm innovation intensity. With the direct relationship of the perceptions of team support for innovation variable to entrepreneurial firm innovation intensity, the mediation relationship produced by the team innovation intensity is partial. This happens because the level of innovation intensity generated by the team also plays an important role as an influencer in team support for innovation and the entrepreneurial firm innovation intensity. Based on the data obtained, there are $81 \%$ of companies whose teamwork is introduced as an innovation of the company. The intensity of service business innovation generated by the team is at a high level, there are $84.8 \%$ of work teams that have introduced innovations in the last 6 months. Therefore, the level of innovation of entrepreneurship services is driven by the capacity of the company that is creatively utilizing new knowledge and network relations[68], [69]. The main challenge faced by service companies is competition and the level of intensity in strategic choices and overall company performance [70].

\section{Conclusion}

Overall, the variables in this study have a positive and significant effect on entrepreneurial firm innovation intensity. With high perceptions of individual creative skills and perceptions of team support for employee innovation, this makes individuals are more motivated to contribute more in supporting overall business performance and view the business or company they work with to be more successful. Teams with members who are creative, respect each other, and are constantly looking for ways to increase innovation was found to affect the intensity of a company's innovation beneficially.

This study has several limitations as follows which is the research sample consisting of employees who work in creative service businesses in Indonesia. The research scope covers one type of business industry (creative industry), thus limiting the potential for generalization to the entire business industry in one country. With research that is carried out extensively on all types of creative industry sectors, the research undertaken does not take a specific approach to see how innovation affects each sector in the creative industry. With limited access and time obtained, the data obtained cannot cover all cities in Indonesia, but most of the data covers areas around Java and Sumatra. In researching entrepreneurial firm innovation intensity, this study uses variables related to individual perceptions and teams. Other variables related to the results of company innovation are not the object of this study. This research was conducted in cross-sectional.

Based on the limitations of this study, it would be better if further research focused on different categories of a company. The industry understudy can be specific to one type of creative industry sector so that it can examine the specific influence of research variables not in a large area of research topic because it requires a different approach in each type of creative industry sector. Future research can also research the scope of cities. Data related to the size of the business, the length of time the business has been running can be collected during the data collection process. Besides, in analyzing the data obtained, further research can take a different approach to teams with more members or teams with fewer members. Types of data collection through a personal approach or case studies can be done to provide additional perspectives on this research topic. Longitudinal data collection can be done to see the contribution of team and individual performance with a longer time to the intensity of the company's innovation.

\section{Acknowledgment}

The authors gratefully acknowledge the support of institution towards the completion of the work.

\section{References}

A. M. Noice, "5 Ways to Boost Creativity in Your Business," Feb. 2016. .

B. M. Lukeš, "Supporting Entrepreneurial Behavior and Innovation in Organizations," Cent. Eur. Bus. Rev., vol. 1, no. 2, pp. 29-36, 2012, doi: 10.18267/j.cebr.15.

C. S. Solhi and E. Rahmanian Koshkaki, "The 
antecedents of entrepreneurial innovative behavior in developing countries, a networked grounded theory approach (case study Iran)," J. Entrep. Emerg. Econ., vol. 8, no. 2, pp. 225-262, Jun. 2016, doi: 10.1108/JEEE-072015-0038.

D. F. Sözbilir, "The interaction between social capital, creativity and efficiency in organizations,' Think. Ski. Creat., vol. 27, pp. 92-100, Mar. 2018, doi: 10.1016/j.tsc.2017.12.006.

E. K. V. Duhamel, "Bringing us back to our creative senses: Fostering creativity in graduate-level nursing education: A literary review," Nurse Education Today, vol. 45. Churchill Livingstone, pp. 51-54, Oct. 2016, doi: 10.1016/j.nedt.2016.06.016.

F. N. Hardika et al., "Manipulative Movement Based on Information Technology Games for School Children Aged 10-12 Years," Indian Journal of Public Health Research and Development, vol. 11, no. 1. Institute of Medico-legal Publications Private Limited, p. 1772, 2020, doi: 10.37506/V11/I1/2020/IJPHRD/194107.

G. R. F. Ishak and S. Somadi, "Analisis Efisiensi Industri Kreatif Unggulan Kota Bandung Dengan Pendekatan Data Envelopment Analysis," Competitive, vol. 14, no. 1, p. 1, 2019, doi: 10.36618/competitive.v14i1.503.

H. L. Hansan, "Getting creative in Indonesia | The ASEAN Post," The Asean Post, Jul. 2019. .

I. R. Gholami, D. Añón Higón, and A. Emrouznejad, "Hospital performance: Efficiency or quality? Can we have both with IT?," Expert Syst. Appl., vol. 42, no. 12, pp. 5390-5400, Jul. 2015, doi: 10.1016/J.ESWA.2014.12.019.

J. T. Savino, A. Messeni Petruzzelli, and V. Albino, "Teams and lead creators in cultural and creative industries: evidence from the Italian haute cuisine," J. Knowl. Manag., vol. 21, no. 3, pp. 607-622, May 2017, doi: 10.1108/JKM-09-2016-0381

K. M. H. Chen, Y. Y. Chang, and J. Y. Pan, “Typology of creative entrepreneurs and entrepreneurial success," J. Enterprising Communities, vol.
12, no. 5, pp. 632-656, Nov. 2018, doi: 10.1108/JEC-07-2017-0041

L. Y. Mayasari and T. Chandra, "Social capital for knowledge management system of the creative industry," J. Enterprising Communities, vol. 14, no. 4, pp. 481-494, Jul. 2020, doi: 10.1108/JEC-01-2020-0008.

M. B. W. Hoffman, R. D. Sellers, and J. Skomra, "The impact of client information technology capability on audit pricing," Int. J. Account. Inf. Syst., vol. 29, pp. 59-75, 2018, doi: https://doi.org/10.1016/j.accinf.2018.03.002.

N. H. S. Saragih, T. M. Simatupang, and Y. Sunitiyoso, "Multi-actor innovation in the music industry: a state of the art review," International Journal of Innovation Science, vol. 10, no. 4. Emerald Group Publishing Ltd., pp. 430-453, Dec. 2018, doi: 10.1108/IJIS-07-2017-0065.

O. A. H. Y. Hon and S. S. Lui, "Employee creativity and innovation in organizations: Review, integration, and future directions for hospitality research," Int. J. Contemp. Hosp. Manag., vol. 28, no. 5, pp. 862-885, May 2016, doi: 10.1108/IJCHM-09-2014-0454

P. M. Bettiol, E. Di Maria, and R. Grandinetti, "Codification and creativity: Knowledge management strategies in KIBS," J. Knowl. Manag., vol. 16, no. 4, pp. 550-562, Jul. 2012, doi: 10.1108/13673271211246130

Q. D. Valgeirsdottir and B. Onarheim, "Studying creativity training programs: A methodological analysis," Creat. Innov. Manag., vol. 26, no. 4, pp. 430-439, Dec. 2017, doi: 10.1111/caim.12245.

R. L. Zocche, I. C. de Paula, S. E. Kunrath, V. L. M. Martins, and F. H. Lermen, "Variables that influence creativity in perception of professionals: A case study in innovative Brazilian companies," Think. Ski. Creat., vol. 29, pp. 170-184, Sep. 2018, doi: 10.1016/j.tsc.2018.07.002.

S. J. C. Neto, J. A. Filipe, and A. B. Caleiro, "Creativity and innovation: A contribution of behavioral economics," Int. J. Innov. Stud., 
vol. 3, no. 1, pp. 12-21, Mar. 2019, doi: 10.1016/j.ijis.2019.06.003.

T. L. V. Ngo, N. P. Nguyen, J. Lee, and V. Andonopoulos, "Mindfulness and job performance: Does creativity matter?," Australas. Mark. J., Jan. 2020, doi: 10.1016/j.ausmj.2019.12.003.

U. E. L. Ghazi and M. Goede, "Creative industries: a case study of Isfahan, Iran,” Int. J. Soc. Econ., vol. 46, no. 2, pp. 271-287, Feb. 2019, doi: 10.1108/IJSE-09-2017-0409.

V. A. Prawata, "Creative User Generated Urbanism," Procedia - Soc. Behav. Sci., vol. 184, pp. 232 239, May 2015, doi: 10.1016/j.sbspro.2015.05.084.

W. K. Matzler, D. E. Abfalter, T. A. Mooradian, and F. Bailom, "Corporate culture as an antecedent of successful exploration and exploitation," Int. J. Innov. Manag., vol. 17, no. 5, p. 1350025, Oct. 2013, doi: $10.1142 / \mathrm{S} 1363919613500254$.

X. K. Ghosh, "Developing organizational creativity and innovation: Toward a model of selfleadership,employee creativity,creativity climate and workplace innovative orientation," Manag. Res. Rev., vol. 38, no. 11, pp. 11261148, Nov. 2015, doi: 10.1108/MRR-012014-0017.

Y. M. Gasparin and M. Quinn, "The INCITE model of policy development for the creative industries: the case of Vietnam," J. Asian Bus. Econ. Stud., 2020, doi: 10.1108/JABES-12-20190125 .

Z. C. R. Li, C. X. Li, and C. J. Lin, "How and when team regulatory focus influences team innovation and member creativity," Pers. Rev., vol. 47, no. 1, pp. 95-117, Feb. 2018, doi: 10.1108/PR-09-2016-0236.

AA. L. K. Gundry, L. F. Ofstein, and J. R. Kickul, "Seeing around corners: How creativity skills in entrepreneurship education influence innovation in business," Int. J. Manag. Educ., vol. 12 , no. 3 , pp. 529-538, Nov. 2014, doi: 10.1016/j.ijme.2014.03.002.
BB. J. O. Damoah and A. Ntsiful, "Childcare demands and employee performance: The moderating influence of team support," Team Perform. Manag., vol. 22, no. 1-2, pp. 36-50, Mar. 2016, doi: 10.1108/TPM-09-2015-0038.

CC. V. Rousseau, C. Aubé, and S. Tremblay, "Team coaching and innovation in work teams: An examination of the motivational and behavioral intervening mechanisms," Leadersh. Organ. Dev. J., vol. 34, no. 4, pp. 344-364, Jun. 2013, doi: 10.1108/LODJ-082011-0073.

DD. M. A. West and N. R. Anderson, "Innovation in top management teams," J. Appl. Psychol., vol. 81, no. 6, pp. 680-693, 1996, doi: 10.1037/0021-9010.81.6.680.

EE. H. Jiao, Y. Wang, and M. Liu, "The effect of the social network of the top management team on innovation in cultural and creative industries," J. Chinese Hum. Resour. Manag., vol. 10 , no. $1 / 2$, pp. 4-18, Oct. 2019, doi: 10.1108/JCHRM-10-2018-0021.

FF.T. M. Amabile, "Creativity in context: Update to 'The Social Psychology of Creativity.' PsycNET," APA PsycnNet, 2016, Accessed: May 21, 2020. [Online]. Available: https://psycnet.apa.org/record/1996-97996000.

GG. J. Ferreira, A. Coelho, and L. Moutinho, "Dynamic capabilities, creativity and innovation capability and their impact on competitive advantage and firm performance: The moderating role of entrepreneurial orientation," Technovation, vol. 92-93, p. 102061, Apr. 2020, doi: 10.1016/j.technovation.2018.11.004.

HH. S. E. Meidt et al., "A model for the onset of self-gravitation and star formation in molecular gas governed by galactic forces: II. the bottleneck to collapse set by cloudenvironment decoupling," arXiv: Astrophysics of Galaxies. 2020, doi: 10.3847/1538-4357/AB7000.

II. M. Matsuo, "Effects of team unlearning on 
employee creativity: The mediating effect of individual reflection," J. Work. Learn., vol. 30, no. 7, pp. 531-544, Sep. 2018, doi: 10.1108/JWL-03-2018-0045.

JJ. C. R. Li, C. X. Li, and C. J. Lin, "The effect of individual task conflict on employee creativity: A moderated mediation model," Think. Ski. Creat., vol. 31, pp. 112-124, Mar. 2019, doi: 10.1016/j.tsc.2018.11.006.

KK. P. G. Bain, L. Mann, and A. Pirola-Merlo, "The innovation imperative," Small Gr. Res., vol. 32, no. 1, pp. 55-73, Feb. 2001, doi: $10.1177 / 104649640103200103$.

LL. N. M. Benazzouz, "Entrepreneurial Orientation and Innovation Intensity: A synthetic literature review," Int. Entrep. Rev., vol. 5, no. 2, pp. 23-26, 2019.

MM. H. Zacher and K. Rosing, "Ambidextrous leadership and team innovation," Leadersh. Organ. Dev. J., vol. 36, no. 1, pp. 69-80, 2015, doi: 10.1108/LODJ-11-2012-0141.

NN. T. S. Suifan, S. Alhyari, and R. J. Sweis, "A moderated mediation model of intragroup conflict," Int. J. Confl. Manag., vol. 31, no. 1, pp. 91-114, Sep. 2019, doi: 10.1108/IJCMA05-2019-0084.

OO. J. de Jong, "Measuring innovative intensity Scale construction," Zoertemeer, Mar. 2000.

PP.Y. C. Liao and K. H. Tsai, "Innovation intensity, creativity enhancement, and eco-innovation strategy: The roles of customer demand and environmental regulation," Bus. Strateg. Environ., vol. 28, no. 2, pp. 316-326, Feb. 2019, doi: 10.1002/bse.2232.

QQ. K.-H. Tsai and S. C.-T. Huang, "Service creativity reinforcement and firm performance," J. Serv. Manag., vol. 31, no. 1, pp. 1-23, Dec. 2019, doi: 10.1108/JOSM-022018-0041.

RR. C. Grimpe and U. Kaiser, "Balancing internal and external knowledge acquisition: The gains and pains from R \& D outsourcing," $J$. Manag. Stud., vol. 47, no. 8, pp. 1483-1509, Dec. 2010, doi: 10.1111/j.1467- 6486.2010.00946.x.

SS.R. Huggins and P. Thompson, "Entrepreneurship, innovation and regional growth: a network theory," Small Bus. Econ., vol. 45, no. 1, pp. 103-128, Jun. 2015, doi: 10.1007/s11187015-9643-3.

TT. J. Tang and P. J. Murphy, "Prior knowledge and new product and service introductions by entrepreneurial firms: The mediating role of technological innovation," J. Small Bus. Manag., vol. 50, no. 1, pp. 41-62, Jan. 2012, doi: 10.1111/j.1540-627X.2011.00343.x.

UU. K. T. Goh, P. S. Goodman, and L. R. Weingart, “Team Innovation Processes," Small Gr. Res., vol. 44, no. 2, pp. 159-194, Apr. 2013, doi: $10.1177 / 1046496413483326$.

VV. H. Lee, J. Lee, and S. Lee, "Exploring the internal and external teamwork in SI team: An application of Q methodology," in ACM International Conference Proceeding Series, Dec. 2017, pp. 437-440, doi: 10.1145/3176653.3176681.

WW. A. Açikgöz and A. Günsel, "The effects of organizational climate on team innovativeness," in Procedia - Social and Behavioral Sciences, 2011, vol. 24, pp. 920 927, doi: 10.1016/j.sbspro.2011.09.102.

XX. J. D. Houghton and T. C. DiLiello, "Leadership development: The key to unlocking individual creativity in organizations," Leadersh. Organ. Dev. J., vol. 31, no. 3, pp. 230-245, 2010, doi: 10.1108/01437731011039343.

YY. S. Seyr and A. Vollmer, "Socio-moral climate, debate, and decision comprehensiveness interplay for team innovation," Int. J. Confl. Manag., vol. 25, no. 2, pp. 105-123, Apr. 2014, doi: 10.1108/IJCMA-08-2012-0060.

ZZ. J. Daspit, C. J. Tillman, N. G. Boyd, and V. Mckee, "Cross-functional team effectiveness: An examination of internal team environment, shared leadership, and cohesion influences," Team Perform. Manag., vol. 19, no. 1, pp. 3456, Mar. 2013, doi: 


\section{$10.1108 / 13527591311312088$}

AAA. X. Xie, Y. Wu, and S. Zeng, "A theory of multi-dimensional organizational innovation cultures and innovation performance in transitional economies: The role of team cohesion," Chinese Manag. Stud., vol. 10, no. 3, pp. 458-479, Aug. 2016, doi: 10.1108/CMS-01-2016-0023.

BBB. S. B. Choi and C. Williams, "The impact of innovation intensity, scope, and spillovers on sales growth in Chinese firms," Asia Pacific J. Manag., vol. 31, no. 1, pp. 25-46, Mar. 2014, doi: 10.1007/s10490-012-9329-1.

CCC. L.-J. Chen, C.-C. Chen, and W.-R. Lee, "Strategic Capabilities, Innovation Intensity, and Performance of Service Firms," J. Serv. Sci. Manag., vol. 01, no. 02, pp. 111-122, Aug. 2008, doi: 10.4236/jssm.2008.12011.

DDD. L. Amanda, F. Yanuar, and D. Devianto, “Uji Validitas dan Reliabilitas Tingkat Partisipasi Politik Masyarakat Kota Padang," J. Mat. $U N A N D$, vol. 8, no. 1, p. 179, 2019, doi: 10.25077/jmu.8.1.179-188.2019.

EEE. A. A. Bakar and A. Afthanorhan, "Confirmatory Factor Analysis on Family Communication Patterns Measurement," Procedia - Soc. Behav. Sci., vol. 219, pp. 3340, May 2016, doi: 10.1016/j.sbspro.2016.04.029.

FFF. F. S. Chandra and D. Novita, "Analisis Penerimaan Masyarakat Terhadap Layanan Transportasi Online Menggunakan UTAUT (Unified Theory of Acceptance and Use of Technology)," JTSI, vol. 1, no. 1, pp. 23-33, Apr. 2020.

GGG. H. Dadgostar, S. Nedjat, E. Dadgostar, and G. Soleimany, "Translation and Evaluation of the Reliability and Validity of Eating Disorder Inventory-3 Questionnaire Among Iranian University Students," Asian J Sport. Med, vol. 8, no. 2, p. 13950, 2017, doi: 10.5812/asjsm. 13950.

HHH. K. Karakaya-Ozyer and B. Aksu-Dunya, “A review of structural equation modeling applications in Turkish educational science literature, 2010-2015," Int. J. Res. Educ. Sci., vol. 4, no. 1, pp. 279-291, 2018, doi: 10.21890/ijres.383177.

III. N. S. Davcik, "The use and misuse of structural equation modeling in management research: A review and critique," J. Adv. Manag. Res., vol. 11, no. 1, pp. 47-81, Apr. 2014, doi: 10.1108/JAMR-07-2013-0043.

JJJ.D. W. Wondola, S. N. Aulele, and F. K. Lembang, "Partial Least Square (PLS) Method of Addressing Multicollinearity Problems in Multiple Linear Regressions (Case Studies: Cost of electricity bills and factors affecting it)," in Journal of Physics: Conference Series, Feb. 2020, vol. 1463, no. 1, p. 12006, doi: 10.1088/1742-6596/1463/1/012006

KKK. E. P. Putri and M. Abdulrahim, "Development of Creative Industry in Indonesia Based on Local Culture," Protests Riots Past Present Futur. Perspect., no. February, pp. 47-75, 2018, doi: 10.1016/j.arthro.2012.05.044.

LLL. "Services, value added (\% of GDP) | Data," The World Bank, 2019. .

MMM. A. H. Y. Hon and S. S. Lui, "Employee creativity and innovation in organizations," Int. J. Contemp. Hosp. Manag., vol. 28, no. 5, pp. 862-885, 2016, doi: 10.1108/ijchm-092014-0454.

NNN. M. N. Hurtado Justiniano, J. Valls-Pasola, and N. Jaria Chacon, “Art as a strategic element for innovation in gastronomic experiential services: The role of teamwork," Team Perform. Manag., vol. 24, no. 5-6, pp. 316330, Aug. 2018, doi: 10.1108/TPM-05-20170022

OOO. J. Gao, J. Kang, C. Zhang, and W. Gang, "Energy performance and operation characteristics of distributed energy systems with district cooling systems in subtropical areas under different control strategies," Energy, vol. 153, pp. 849-860, 2018, doi: https://doi.org/10.1016/j.energy.2018.04.098.

PPP. J. Kandampully, T. (Christina) Zhang, and A. 
Bilgihan, "Customer loyalty: A review and future directions with a special focus on the hospitality industry," Int. J. Contemp. Hosp. Manag., vol. 27, no. 3, pp. 379-414, Apr. 2015, doi: 10.1108/IJCHM-03-2014-0151.

QQQ. N. Bhatnagar and A. Kumar Gopalaswamy, "The role of a firm's innovation competence on customer adoption of service innovation," Manag. Res. Rev., vol. 40, no. 4, pp. 378-409, Apr. 2017, doi: 10.1108/MRR-11-2015-0280.

RRR. T. Anning-Dorson and M. B. Nyamekye, "Engagement Capability, Innovation Intensity and Firm Performance: The Role of Competitive Intensity," J. African Bus., pp. 116, Aug. 2020, doi: 10.1080/15228916.2020.1790914. 